(C) 2013

Харів І. І., кандидат біологічних наук

Львівський національний університет ветеринарної медицини та біотехнологій імені С. 3. Гжицького

\title{
ПОКАЗНИКИ КЛІТИННОГО ІМУНІТЕТУ ІНДИКІВ, УРАЖЕНИХ АСОЦІАТИВНОЮ ЕЙМЕРІОЗО-ГІСТОМОНОЗНОЮ ІНВАЗІЕЮ ТА ЛІКОВАНИХ БРОВІТАКОКЦИДОМ СУКУПНО З ПЛОДАМИ РОЗТОРОПШІ ПЛЯМИСТОї
}

\section{Рецензент - доктор ветеринарних наук В. І. Завірюха}

\begin{abstract}
У слизовій оболонці кищечника еймерії та гістомонади виділяють продукти метаболізму, щзо діють токсично на різні системи і тканини індиків. Вони знижують активність сенсибілізованих клітин (клітинний тип), пригнічують специифічну фазу імунітету, представлену антитілами (гуморальний тип), сповільнюють неспециффічну фазу імунітету, щзо представлена різними імунними клітинами. За еймеріозо-гістомонозної інвазії в індиків швидше й повніше відбувається відновлення показників неспецифічного імунітету.
\end{abstract}

Ключові слова: фармакологія, бровітакокичд, розторопша плямиста, еймерії, гістомонади, клітинний імунітет.

Постановка проблеми. Кількість племінних і товарних фермерських господарств із вирощування індиків в Україні останнім часом дещо скоротилася, водночас поголів'я згаданих вище птахів значно збільшилося у присадибних господарствах. Збільшення обсягів виробництва м'яса птиці можна досягти за умов застосування науково обгрунтованої системи ведення цієї галузі. Особливого значення наразі набуває питання всебічного вивчення інфекційних та інвазійних захворювань. Важливість цього питання полягає в ефективності своєчасної діагностики та розробки ефективної терапії.

Аналіз останніх досліджень і публікацій, у яких започатковано розв'язання проблеми. На індичат у ранньому філогенетичному розвитку діють різні стрес-фактори: неповноцінна годівля, неадекватні умови утримання, бактеріальні інфекції, гельмінтозні й прото-зоонозні інвазії $[1,3,5]$. Це, в свою чергу, призводить до зниження природної резистентності організму та пригнічення кровотворної функції кісткового мозку $[2,4,6]$. Для підвищення імунного стану організму тварин і птиці у практиці ветеринарної медицини застосовують різні імуностимулювальні препарати - КАФІ, Т-активін, лейкоген, гомотин, імуноглобуліни, тимоген, камізол, тощо $[7,8]$. Недолік цих препаратів полягає у тому, що їх вводять парентерально, а, як відомо, птиця до 3-місячного віку важко переносить парентеральні ін'єкції.

Для підвищення імунного стану організму індиків безпечнішими й зручними в застосуванні $\epsilon$ рослинні препарати, які додають до корму. Їхня імуностимулювальна дія не поступається аналогічному впливу хімічних препаратів і проявляє «м'яку» імуностимулювальну дію. До рослинних препаратів, що проявляють високу імуностимулювальну дію, відносяться трава ехінацеї та плоди розторопші плямистої. На даний час ці рослини широко вивчаються і застосовуються в лікувальній практиці гуманної медицини, проте їм ще не надається належної уваги у практиці ветеринарної медицини, зокрема у птахівництві. Згідно $з$ даними іноземних літературних джерел, дане питання мало вивчене, а в Україні такий напрям розробляється вперше.

Мета і завдання досліджень. Метою наших досліджень було вивчити вплив самого бровітакокциду та за сукупного застосування з плодами розторопші плямистої на нормалізацію показників клітинного імунітету індиків за спонтанного ураження асоційованою еймеріозо-гістомонозною інвазією.

Завдання досліджень: встановити лікувальну ефективність еймеріоцидного препарату власне бровітакокциду та в разі сукупного застосування з плодами розторопші плямистої; порівняти терапевтичну ефективність обох способів лікування індиків за виникнення асоціативної еймеріозно-гістомонозної інвазії.

Матеріали і методи досліджень. Для дослідження впливу бровітакокциду та плодів розторопші плямистої на нормалізацію морфологічних i біохімічних показників імунної системи індиків за спонтанного ураження асоційованою еймеріозогістомонозною інвазією сформували три групи дослідних індичат по 20 птахів у кожній групі.

Індичат першої групи лікували бровітакокцидом, який додавали в дозі 2 г/кг корму. Індича- 
там другої групи додавали бровітакокцид 2 г/кг та порошок розмелених плодів розторопші плямистої - 2 г/кг корму. Препарати додавали з вологим комбікормом упродовж п'яти діб поспіль. Контрольною групою були нормальні показники крові третьої групи клінічно-здорових індичат аналогів із сумісного брудера.

У кожній групі чорнилом помітили по 20 індичат, від яких із підкрильцевої вени брали кров на 1-у, 3-ю, 5-у доби лікування та через 5 діб після одужання.

У крові визначали кількість лейкоцитів, лімфоцитів, Т-лімфоцитів, В-лімфоцитів.

Результати дослідження. Імунна система організму тварин і птиці забезпечує резистентність організму проти бактеріальних і вірусних інфекцій. За гельмінтозних і протозоонозних захворюваннь пригнічується функціональний стан імунної системи й настає вторинний імунодефіцит.

У хворих індиків (табл. 1) внаслідок дії токсинів, що виділяють протозоо до лікування встановлено лейкоцитоз. Кількість лейкоцитів становила $5,98 \pm 0,56$ Г/л проти $3,45 \pm 0,14$ Г/л у клінічно здорової птиці, що на 73,3 \% більше $(\mathrm{P}<0,001)$. На третю добу лікування бровітакокцидом ї кількість зменшилася вдвічі, а на п'яту добу була на 12,3 \% більшою від норми. За п’ять діб після клінічного одужання кількість лейкоцитів була на 9 \% більшою від контрольної групи, що вказує на наявність запальних процесів слизової оболонки в місцях, де паразитують еймерії та гістомонади.

В індиків, яких лікували бровітакокцидом, повільно нормалізувалися показники клітинного імунітету. До лікування загальна кількість лімфоцитів становила $62,2 \pm 2,15$ Г/л проти $88,6 \pm 2,2$ Г/л у клінічно здорових, що на $42,4 \%$ менше $(\mathrm{p}<0,001)$. На третю добу лікування кількість лімфоцитів залишалася на низькому рівні, дещо підвищилася на п’яту добу (період клінічного одужання) i на десяту добу (п'ята доба після лікування) їх кількість була на $20 \%$ менше контрольної групи.

Досить повільно нормалізувалася кількість популяцій лімфоцитів. Зокрема, на період клінічного одужання кількість В-лімфоцитів була на $14,3 \%$, а Т-лімфоцитів - на 10,2\% менше контрольних величин. На такому ж рівні обидві популяції лімфоцитів залишалися і на п'яту добу після клінічного одужання (табл. 1).

При дослідженні показників клітинного імунітету у індиків, лікованих бровітакокцидом сукупно із плодами розторопші плямистої, встановлено, що на період клінічного одужання (п'ята доба) кількість лейкоцитів була такою ж, як у клінічно здорових (див. табл.).

Число лімфоцитів у хворих індиків було на $22,7 \%$ менше, порівняно 3 клінічно здоровими. При лікуванні їх кількість на третю добу збільшилася з 72,2 22,5 Г/л до 80,4 $\pm 2,1$ Г/л, а на п'яту добу була такою як у індиків контрольної групи.

Кількість Т- і В-лімфоцитів на третю добу лікування залишалася на низькому рівні, як і до лікування, а на п'яту добу лікування нормалізувалася.

На п'яту добу після клінічного одужання показники клітинного імунітету у індиків, яких лікували бровітакокцидом сукупно із плодами розторопші плямистої, були такими ж, як у клінічно здорових.

\section{Показники клітинного імунітету індиків після задавання бровітакокциду та плодів} розторопші плямистої (M $\pm m ; n=20)$

\begin{tabular}{|c|c|c|c|c|c|}
\hline \multirow{2}{*}{ Показники } & \multirow{2}{*}{ Групи } & \multicolumn{4}{|c|}{ Доба досліджень } \\
\cline { 3 - 6 } Контроль/дослід & & перша & третя & п'ята & десята \\
\hline \multirow{2}{*}{ Лейкоцити, } & К & $3,45 \pm 0,14$ & $3,54 \pm 0,24$ & $3,42 \pm 0,12$ & $3,45 \pm 0,14$ \\
Г/л & Д1 & $5,98 \pm 0,56^{* * *}$ & $4,86 \pm 0,23^{* * *} 4,3$ & $3,84 \pm 0,16^{*}$ & $3,76 \pm 0,12^{*}$ \\
& Д2 & $5,98 \pm 0,56^{* * *}$ & $2 \pm 0,34^{* *}$ & $3,56 \pm 0,36$ & $3,48 \pm 0,26$ \\
\hline \multirow{2}{*}{ Лімфоцити, } & К & $88,6 \pm 2,2$ & $86,2 \pm 2,1$ & $88,2 \pm 1,8$ & $87,4 \pm 1,5$ \\
Г/л & Д1 & $62,2 \pm 3,1^{* * *}$ & $64,5 \pm 2,0 * * *$ & $70,5 \pm 2,1 *$ & $72,6 \pm 1,4 *$ \\
& Д2 & $72,2 \pm 2,1^{* * *}$ & $80,4 \pm 2,5^{*}$ & $86,5 \pm 1,7$ & $86,8 \pm 1,4$ \\
\hline \multirow{2}{*}{ Т-лімфоцити, } & К & $0,12 \pm 0,02$ & $0,12 \pm 0,03$ & $0,11 \pm 0,05$ & $0,11 \pm 0,04$ \\
(Е-РУК), Г/л & Д1 & $0,09 \pm 0,01^{* * *}$ & $0,09 \pm 0,02^{* * *} 0,0$ & $0,10 \pm 0,03^{*}$ & $0,10 \pm 0,05^{*}$ \\
& Д2 & $0,09 \pm 0,01^{* * *}$ & $9 \pm 0,02^{* * *}$ & $0,10 \pm 0,04^{*}$ & $0,12 \pm 0,03$ \\
\hline \multirow{2}{*}{ В-лімфоцити, } & К & $0,32 \pm 0,04$ & $0,33 \pm 0,06$ & $0,32 \pm 0,06$ & $0,33 \pm 0,04$ \\
(ЕАС-РУК), Г/л & Д1 & $0,26 \pm 0,06^{* *}$ & $0,28 \pm 0,04^{*}$ & $0,280 \pm 0,06^{*} 0,31$ & $0,30 \pm 0,06^{*}$ \\
& Д2 & $0,28 \pm 0,04^{*}$ & $0,29 \pm 0,06^{*}$ & $\pm 0,06$ & $0,32 \pm 0,06$ \\
\hline
\end{tabular}

Примітка. Ступінь вірогідності в порівнянні до контрольної групи: $* \mathrm{P}<0,05,{ }^{*} * \mathrm{P}<0,02, * * * \mathrm{P}<0,001$ 
Отже, в результаті проведених досліджень нами встановлено, що в індиків, уражених еймеріозо-гістомонозною інвазією, настає пригнічення клітинного імунітету, що призводить до розвитку вторинного імунодефіциту.

Висновки. За виникнення еймеріозогістомонозної інвазії та при застосуванні для лікування бровітакокциду на період клінічного одужання стан клітинного імунітету суттєво поліпшився. Проте на п'яту добу після одужання на 20 \% нижче нормальних величин була загальна кількість лімфоцитів і на $10 \%$ - кількість Т- і В-лімфоцитів, що вказує на неповне відновлення функціонального стану клітинної ланки імуніте-

\section{БІБЛІОГРАФІЯ}

1. Атлас гельмінтів тварин / І. С. Дахно, А. В. Березовський, В. Ф. Галат [та ін.] - К. : Ветінформ, 2001. - $118 \mathrm{c}$.

2. Богач М. В. Паразитарні хвороби індиків фермерських і присадибних господарствах півдня України / М. В. Богая, І. Л. Тараненко // Аграрний вісник Причорноморя: Зб. наук. праць. Одеса, 2003. - Вип. 21. - С. 311-317.

3. Кобиова Г. Индейки - это выгодно / Г. Кобцова // Птицеводство, 2001. - №4. - С. 18-19.

4. Котельников Г. А. Гельминтологические исследования окружающей среды / Г. А. Котельников. - М. : Росагропромиздат, 1991. - 144 с.

5. Машке I. A. Ектопаразити птиці в фермерських i присадибних господарствах Крима / I. А. Машке, О. I. Захаров // Вет. медицина : Міжвід. темат. наук. зб. - Х., 2002. - №80. - ту. Швидке і повне відновлення клітинного імунітету в індиків, уражених еймеріозо-гістомонозною інвазією, встановлено, якщо бровітакокцид задавали сукупно 3 плодами розторопші плямистої. Плоди містять групу флаволігнанів під назвою «Силімарин», що діє імуностимулювально за розвитку вторинного імунодефіцитного стану організму.

Подальші дослідження у даному напрямі будуть спрямовані на вивчення впливу бровітакокциду сукупно із плодами розторопші плямистої на імунну систему організму індиків за еймеріозо-гістомонозної інвазії.

\section{423-428.}

6. Тимофеев Б. А. Эймериоз птиц / Б. А. Тимофеев // Ветеринарный консультант. - М., 2004. №5. - C. 6-10.

7. Харів I. I. Вплив бровітакокциду та плодів розторопші плямистої на морфологічні показники крові інтактних індиків / I. I. Харів // Науково-технічний бюлетень Інституту біології тварин і ДНДКІ ветпрепаратів та кормових добавок. Львів, 2011. - Вип. 12. - №3-4. - С. 239-243.

8. Харів I. I. Стан імунної системи індиків, уражених еймеріозо-гістомонозною інвазією / I. I. Харів // Науковий вісник Львівського національного університету ветеринарної медицини та біотехнологій імені С. З. Гжицького. - Том 13. № 4(50). - Ч. 1, 2011. - С. 481-484. 